\title{
Jak leczyć pacjenta z nowo rozpoznaną amyloidozą łańcuchów lekkich pośredniego ryzyka? Rola doksycykliny w terapii amyloidozy z zajęciem serca
}

\section{How to treat a patient with intermediate-risk light chain amyloidosis? The role of doxycycline in cardiac amyloidosis}

\author{
Aleksander Salomon-Perzyński ${ }^{1}$, Agnieszka Końska ${ }^{1}$, Bartosz Puła ${ }^{1}$, \\ Justyna Łyczkowska-Piotrowska ${ }^{2}$, Krzysztof Jamroziak ${ }^{1}$ \\ ${ }^{1}$ Klinika Hematologii, Instytut Hematologii i Transfuzjologii, Warszawa, Polska \\ ${ }^{2}$ Klinika Kardiologii i Nadciśnienia Tętniczego, Centralny Szpital Kliniczny \\ Ministerstwa Spraw Wewnętrznych i Administracji, Warszawa, Polska
}

\begin{abstract}
Streszczenie
Leczenie pacjentów z amyloidozq tańcuchów lekkich (amyloidozq AL) stanowi wyzywanie w codziennej praktyce klinicznej. Choć uzyskanie gtęokiej i dtugotrwatej odpowiedzi hematologicznej w gtównej mierze decyduje o powodzeniu terapii, to w odniesieniu do tej grupy chorych szczególnego znaczenia nabiera odpowiednie prowadzenie leczenia wspomagajacego. Ponieważ amyloidoza AL stanowi interdyscyplinarna jednostke chorobowa, to proces terapeutyczny powinien być koordynowany przez interdyscyplinarny zespót ztożony $z$ hematologa, kardiologa, nefrologa, gastroenterologa, neurologa i dietetyka klinicznego. W niniejszej pracy przedstawiono strategie postepowania u pacjenta z nowo rozpoznana wielouktadowq amyloidoza AL pośredniego ryzyka, z zajęciem serca, leczonego w Klinice Hematologii Instytutu Hematologii i Transfuzjologii w Warszawie, u którego poza standardowa chemioterapia zastosowano doksycykline.
\end{abstract}

Słowa kluczowe: amyloidoza łańcuchów lekkich, amyloidoza serca, dyskrazje plazmocytarne, doksycyklina

Hematologia 2018; 9, 3: 245-253

\begin{abstract}
Treatment of patients with light chain amyloidosis (AL amyloidosis) is a challenge in routine clinical practice. Although deep and durable hematologic response is crucial for the success of the therapy, in this group of patients the proper conduct of supportive care becomes particularly important. Because AL amyloidosis is an interdisciplinary disease entity, the therapeutic process should be coordinated by an interdisciplinary team consisting of a hematologist, cardiologist, nephrologist, gastroenterologist, neurologist and clinical dietician. In this paper, we present a strategy for treating a patient with a newly diagnosed systemic intermediate-risk AL amyloidosis with cardiac involvement in the Department of Hematology of the Institute of Hematology and Transfusion Medicine in Warsaw, in which, apart of standard chemotherapy, doxycycline was used.
\end{abstract}

Key words: light chain amyloidosis, cardiac amyloidosis, plasma cell dyscrasias, doxycycline

Hematologia 2018; 9, 3: 245-253

Adres do korespondencji: Aleksander Salomon-Perzyński, Klinika Hematologii, Instytut Hematologii i Transfuzjologii, ul. Indiry Gandhi 14, 02-776 Warszawa, faks 223496 335, e-mail: salomon.perzynski@gmail.com 


\section{Wprowadzenie}

Amyloidoza łańcuchów lekkich (amyloidoza AL) stanowi najczęstszą postać amyloidoz układowych, tj. grupy schorzeń, w przebiegu których dochodzi do formowania się w tkankach i narządach wewnętrznych depozytów amyloidowych indukujących lokalną reakcję zapalną, zaburzających cytoarchitektonikę tkankową oraz interferujących w homeostazę macierzy pozakomórkowej, co ostatecznie skutkuje zaburzeniem funkcjonowania lub rozwojem niewydolności zajętych narządów [1-3].

Ze względu na niską zachorowalność na amyloidozę AL, szerokie spektrum manifestacji klinicznej, trudności w diagnostyce różnicowej oraz wysokie ryzyko ujawnienia się działań niepożądanych stosowanych terapii leczenie tej jednostki chorobowej powinno się odbywać przede wszystkim w wysoce specjalistycznych ośrodkach doświadczonych w leczeniu amyloidozy, a proces terapeutyczny powinien być koordynowany przez interdyscyplinarny zespół złożony $z$ hematologa, kardiologa, nefrologa, neurologa, gastroenterologa i dietetyka klinicznego $z$ możliwością dodatkowych konsultacji przez lekarzy innych specjalizacji.

$\mathrm{W}$ niniejszej pracy przedstawiono strategię postępowania u pacjenta $z$ nowo rozpoznaną wieloukładową amyloidozą AL leczonego w Klinice Hematologii Instytutu Hematologii i Transfuzjologii w Warszawie, ze szczególnym uwzględnieniem roli terapii doksycykliną w przypadkach amyloidozy AL przebiegających z zajęciem mięśnia sercowego.

\section{Opis przypadku (1)}

Pacjent $\mathrm{w}$ wieku 58 lat $\mathrm{z}$ rozpoznaną, na podstawie badania histopatologicznego bioptatu nerki, amyloidozą zostal przyjęty do Kliniki Hematologii Instytutu Hematologii i Transfuzjologii w Warszawie w grudniu 2015 roku w celu ustalenia podtypu amyloidozy oraz podjęcia dalszych decyzji klinicznych. W ciągu ostatnich 6 miesięcy u chorego obserwowano postępujące ograniczenie tolerancji wysiłku fizycznego, ujawnienie się objawów hipotensji ortostatycznej (w tym nawracających zasłabnięć) oraz dolegliwości bólowych o charakterze neuropatycznym w zakresie dystalnych części kończyn dolnych i górnej połowy klatki piersiowej. Pacjent nie podawał w wywiadzie typowych dla szpiczaka plazmocytowego bólów kostnych. Wśród istotnych wspólistniejących u niego schorzeń występowały choroba niedokrwienna serca, przebyte wirusowe zapalenie wątroby typu B oraz depresja.
W ocenie hematologicznej stężenie wolnych łańcuchów lekkich (FLC, free light chains) typu kappa i lambda wynosiło, odpowiednio, 20 i 114 $\mathrm{mg} / 1$, różnica stężeń między FLC klonalnymi i nieklonalnymi ( $\mathrm{dFLC}$, difference between involved and uninvolved FLCs ) - $94 \mathrm{mg} / 1$. Stosunek stężeń FLC kappa i lambda (rFLC K/L, FLC kappa and lambda ratio $)-0,18$. W trepanobioptacie plazmocyty stanowiły $20 \%$ utkania szpiku kostnego, ponadto w barwieniu czerwienią Kongo w ścianie naczyń krwionośnych uwidoczniono złogi amyloidu. W badaniu immunofiksacji surowicy nie stwierdzono obecności białka monoklonalnego. Podobnie nie stwierdzono odchyleń w obrazie morfologii krwi obwodowej. Wartości kreatyninemii i kalcemii pozostawały w granicach normy. W rentgenogramach kośćca nie uwidoczniono zmian osteolitycznych.

W ocenie zajęcia serca stężenie N-końcowego propeptydu natriuretycznego typu B (NT-proBNP, $N$-terminal pro-B-type natriuretic peptide) wynosiło $5198 \mathrm{ng} / \mathrm{l}$, a stężenie troponiny I — 0,07 ng/ml. $\mathrm{W}$ badaniu echokardiograficznym uwidoczniono cechy pogrubienia mięśnia lewej komory $z$ wyraźną niejednorodnością echogeniczną, zmianom tym towarzyszyły cechy upośledzonej relaksacji mięśnia lewej komory.

W ocenie zajęcia nerek białkomocz dobowy wynosił około 6 gramów, stężenie kreatyniny $1 \mathrm{mg} / \mathrm{dl}$, natomiast szacunkowy współczynnik filtracji kłębuszkowej (eGFR, estimated glomerular filtration rate) przekraczał $60 \mathrm{ml} / \mathrm{min}$. W badaniu elektroforetycznym moczu dominowały albuminy. W badaniu immunofiksacji moczu stwierdzono obecność śladowej ilości FLC typu lambda.

$\mathrm{W}$ ocenie zajęcia wątroby $\mathrm{w}$ ultrasonografii (USG) jamy brzusznej wymiary wątroby pozostawały w granicach normy. Stwierdzono natomiast nieznaczną hipertransaminazemię (aktywność transferazy alaninowej [AlAT, alanine aminotransferase] i asparaginianowej [AspAT, aspartate aminotransferase] odpowiednio 63 i $39 \mathrm{jm} . / 1$ ) i zwiększoną aktywność gammaglutamylotranspeptydazy (GGTP, gamma-glutamyl transpeptidase) $101 \mathrm{jm} . / 1$, przy prawidłowej aktywności fosfatazy alkalicznej (ALP, alkalic phosphatase) oraz prawidłowych bilirubinemii i koagulogramie.

W ramach klinicznej oceny zajęcia obwodowego układu nerwowego u chorego rozpoznano neuropatię czuciową (2. stopnia wg CTCAE [Common Terminology Criteria for Adverse Events v.4.0]) oraz neuropatię wegetatywną (3. stopnia wg CTCAE) objawiającą się hipotensją ortostatyczną.

Na podstawie całokształtu obrazu klinicznego oraz wyników badań dodatkowych u pacjenta roz- 
poznano wieloukładową amyloidozę AL z zajęciem nerek, serca i obwodowego układu nerwowego. Zważywszy na wywiad w kierunku przebytego wirusowego zapalenia wątroby typu B, brak hepatomegalii i prawidłową aktywność ALP nie rozpoznano zajęcia wątroby w przebiegu amyloidozy AL. W opisanym przypadku zwracał uwagę stosunkowo duży naciek plazmocytarny w szpiku kostnym (u połowy pacjentów $z$ amyloidozą AL plazmocyty stanowią $<10 \%$ utkania szpiku kostnego [1]).

Stopień zaawansowania klinicznego amyloidozy AL ustalono na II według klasyfikacji Mayo Clinic z 2004 roku (wyjściowe stężenie NT-proBNP w zakresie $332-8500 \mathrm{ng} / \mathrm{ml}$; stężenie troponiny I $<0,1 \mathrm{ng} / \mathrm{ml}$ ) [4].

\section{Czy chory kwalifikuje się do}

wysokodawkowanej chemioterapii

wspomaganej autologicznym

przeszczepieniem krwiotwórczych

komórek macierzystych?

Uznaną metodą leczenia pierwszej linii chorych na amyloidozę AL jest wysokodawkowana chemioterapia wspomagana autologicznym przeszczepieniem krwiotwórczych komórek macierzystych (auto-HSCT, autologous hematopoietic stem cell transplantation). Należy jednak zwrócić uwagę, że na podstawie przytoczonych niżej danych literaturowych auto-HSCT powinno być zarezerwowane dla stosunkowo wąskiej grupy chorych cechujących się niskim ryzykiem.

Ostatnio retrospektywną analizę wyników leczenia pacjentów $z$ amyloidozą AL poddawanych auto-HSCT w ciagu ostatnich 20 lat opublikował zespół z Mayo Clinic [5]. Odpowiedź hematologiczną osiągano istotnie częściej u pacjentów leczonych w latach 2010-2016 (kohorta $1, \mathrm{n}=246$ ) aniżeli u chorych leczonych w latach 2003-2009 (kohorta $2, \mathrm{n}=302)$ i $1996-2002($ kohorta $3, \mathrm{n}=124)$ (odsetek obiektywnych odpowiedzi [ORR, objective response rate] $84 \%$ v. $79 \%$ v. $69 \%$ ). Co ważne, $z$ upływem czasu obserwowano znamienne zmniejszenie śmiertelności związanej z leczeniem ([TRM, treatment-related mortality $] 2,4 \%$ v. 8,6\% v. $14,5 \%$ odpowiednio w kohortach 3., 2.i 1.). Mediana przeżycia całkowitego (OS, overall survival) w całej grupie $(\mathrm{n}=672)$ wyniosła 122 miesięcy. W kohorcie 1 . mediana OS nie została osiągnięta, $z$ kolei w kohortach 2. i 3. wynosiła odpowiednio 120 i 75 miesięcy.

Podobne wyniki przedstawili Sanchorawala i wsp. [6]. Mediana OS w grupie 629 pacjentów $z$ amyloidozą AL poddanych HDT-auto-HSCT w ciągu ostatnich 20 lat wyniosła 7,6 roku. Co ważne, przeżycie 15-letnie osiągnęła ponad połowa chorych (57\%) spośród tych, którzy w odpowiedzi na intensywne leczenie osiągnęli całkowitą remisję (CR). W przypadku procedur przeprowadzonych po 2005 roku TRM wyniosło 3,4\%.

Obserwowane w ostatnich 20 latach zmniejszenie TRM i poprawa OS wśród chorych na amyloidozę AL poddawanych auto-HSCT wynika w szczególności ze stopniowo wypracowanych restrykcyjnych kryteriów kwalifikacji pacjenta do auto-HSCT. Kryteria kwalifikacji zaaprobowane przez ośrodki transplantologiczne $z$ doświadczeniem w leczeniu amyloidozy AL w większości są zbieżne (tab. 1, 2). W Klinice Hematologii Instytutu Hematologii i Transfuzjologii w Warszawie pacjentów $z$ amyloidozą AL kwalifikuje się do auto-HSCT głównie na podstawie kryteriów wypracowanych

Tabela 1. Kryteria kwalifikacji chorego na amyloidozę łańcuchów lekkich (AL) do wysokodawkowanej chemioterapii wspomaganej autologicznym przeszczepieniem krwiotwórczych komórek macierzystych opracowane przez ekspertów Mayo Clinic (źródło [8])

Table 1. Mayo Clinic experts' criteria for high-dose therapy followed by autologous hematopoietic stem cell transplantation in patients with light chain (AL) amyloidosis (source [8])

\begin{tabular}{|c|c|}
\hline Parametr kliniczny/laboratoryjny & Wartość \\
\hline Wiek & $<70$ lat \\
\hline Stan sprawności wg ECOG & $0-2$ \\
\hline Stężenie troponiny sercowej T & $<0,06 \mathrm{ng} / \mathrm{ml}$ \\
\hline Skurczowe ciśnienie tętnicze & $>90 \mathrm{mmHg}^{*}$ \\
\hline Klasa niewydolności serca wg NYHA & I-II \\
\hline eGFR & $>30 \mathrm{ml} / \mathrm{min} / 1,73 \mathrm{~m}^{2}$ lub leczenie nerkozastępcze \\
\hline Stopień zajęcia narządowego w przebiegu amyloidozy AL & $\begin{array}{c}\leq 2 \text { istotnie zajęte narządy (serce, wątroba, nerki, } \\
\text { autonomiczny układ nerwowy) }\end{array}$ \\
\hline
\end{tabular}

*Szczególną ostrożność należy zachować u pacjentów ze skurczowym ciśnieniem tętniczym < 100 mm Hg; ECOG — Eastern Cooperative Oncology Group; NYHA — New York Heart Association; eGFR (estimated glomerular filtration rate) — szacunkowy współczynnik przesączania kłębuszkowego 
Tabela 2. Kryteria kwalifikacji chorego na amyloidozę łańcuchów lekkich (AL) do wysokodawkowanej chemioterapii wspomaganej autologicznym przeszczepieniem krwiotwórczych komórek macierzystych opracowane przez ekspertów z Uniwersytetu w Pawii (źródło [7])

Table 2. University of Pavia's experts' criteria for high-dose therapy followed by autologous hematopoietic stem cell transplantation in patients with light chain (AL) amyloidosis [7]

\begin{tabular}{|l|c|}
\hline Parametr kliniczny/laboratoryjny & Wartość \\
\hline Wiek & $<65$ lat \\
\hline Stan sprawności wg ECOG & $0-2$ \\
\hline Stężenie troponiny sercowej T & $<0,06 \mathrm{ng} / \mathrm{ml}$ \\
\hline NT-proBNP & $<5000 \mathrm{ng} / \mathrm{ml}$ \\
\hline Skurczowe ciśnienie tętnicze & $>90 \mathrm{~mm} \mathrm{Hg} \mathrm{w} \mathrm{pozycji} \mathrm{stojącej}$ \\
\hline Klasa niewydolności serca wg NYHA & $>$ II \\
\hline Frakcja wyrzutowa lewej komory & $>45 \%$ \\
\hline eGFR & $>50 \mathrm{ml} / \mathrm{min} / 1,73 \mathrm{~m}^{2}$ lub leczenie nerkozastępcze \\
\hline DLCO & $>50 \%$ \\
\hline
\end{tabular}

ECOG - Eastern Cooperative Oncology Group; NT-proBNP (N-terminal pro-B-type natriuretic peptide) - N-końcowy fragment propeptydu natriuretycznego typu B; NYHA - New York Heart Association; eGFR (estimated glomerular filtration rate) — szacunkowy współczynnik przesączania kłębuszkowego; DLCO (diffusing capacity of lung for carbon monoxide) - pojemność dyfuzyjna płuc dla tlenku węgla

przez zespół Mayo Clinic (tab. 1). Wspomagająco stosuje się kryteria „europejskie” (tab. 2). Ocenia się, że w populacji chorych na amyloidozę AL pacjenci spełniający kryteria kwalifikacji do auto-HSCT (tzw. pacjenci niskiego ryzyka) stanowią jedynie $15-20 \%[7,8]$.

\section{Opis przypadku (2)}

W związku $z$ obserwowaną u pacjenta uporczywą hipotensją, incydentami zasłabnięć, jak również istotnym zajęciem więcej niż dwóch narządów wewnętrznych w przebiegu amyloidozy AL, uznano, że chory nie kwalifikuje się do procedury auto-HSCT.

W tym miejscu warto zauważyć, że w przypadku większości chorych na amyloidozę AL klon nowotworowy jest na tyle mały, że nie jest konieczne leczenie indukujące remisję przed wykonaniem procedury auto-HSCT. Jednak u chorych $z$ nacieczeniem szpiku przekraczającym $10 \%$, jak w przypadku omawianego pacjenta, zaleca się podanie kilku kursów chemioterapii w celu redukcji klonu plazmocytowego przed tym zabiegiem [1].

Który schemat leczenia systemowego amyloidozy AL można uznać

za optymalny dla chorego?

Obecnie u pacjentów $z$ nowo rozpoznaną amyloidozą AL, którzy nie kwalifikują się do -auto-HSCT, ale których stan ogólny pozwala na prowadzenie leczenia systemowego (tzw. pacjenci pośredniego ryzyka) podejmuje się leczenie w oparciu o jeden $z$ trzech schematów chemioterapii, tj. melfalan w skojarzeniu $z$ deksametazonem (MDex), melfalan w skojarzeniu $z$ deksametazonem i bortezomibem (BMDex) oraz bortezomib w skojarzeniu $\mathrm{z}$ cyklofosfamidem i deksametazonem (CyBorD).

Niedawno opublikowano wyniki wstępnej analizy randomizowanego badania III fazy, w którym oceniano skuteczność kliniczną schematu BMDex $\mathrm{w}$ porównaniu $\mathrm{z}$ MDex w leczeniu chorych $\mathrm{z}$ nowo rozpoznaną amyloidozą AL [9]. W grupie chorych leczonych BMDex osiągnięto istotnie wyższy ORR (81\% v. 56\%), przy czym znamiennie częściej obserwowano odpowiedzi głębokie, tj. co najmniej bardzo dobrą odpowiedź częściową (VGPR, very good partial response) - odpowiednio u $64 \%$ pacjentów leczonych według schematu BMDex i $38 \%$ pacjentów leczonych według schematu MDex. Nie wykazano istotnych różnic między badanymi grupami w zakresie uzyskania odpowiedzi sercowej (38\% w grupie leczonej BMDex i $24 \%$ w grupie leczonej MDex) i nerkowej (48\% w obu grupach), niemniej jednak w grupie leczonej według schematu MDex obserwowano granicznie istotną statystycznie tendencję do częstszego występowania progresji sercowej (32\% v. 15\%; $\mathrm{p}=0,054)$. Leczenie według schematu BMDex charakteryzowało się nieznacznie wyższą toksycznością. Wśród ciężkich działań niepożądanych dominowały cytopenie, retencja płynów oraz polineuropatia (odpowiednio 7\%, 6\% i $2 \%$ v. $4 \%, 3 \%$ i $0 \%$ w grupach leczonych BMDex i MDex). We wstępnej analizie wyższy odsetek odpowiedzi uzyskiwany w grupie leczonej BMDex nie przełożył się na poprawę przeżywalności. Ocena, 
czy dołączenie bortezomibu do schematu MDex wiąże się $z$ poprawą OS oraz wyższą częstością odpowiedzi narządowych, wymaga dłuższego okresu obserwacji.

Skuteczność i bezpieczeństwo stosowania schematu CyBorD w leczeniu chorych na nowo rozpoznaną amyloidozę AL oceniono niedawno w dużym badaniu europejskim [10]. Włączono do niego 230 pacjentów leczonych w latach 2006-2013 . Odsetek obiektywnych odpowiedzi wyniósł $60 \%$, przy czym u $43 \%$ pacjentów obserwowano odpowiedzi głębokie, tj. co najmniej VGPR. Odpowiedź sercową i nerkową osiągnięto odpowiednio u $17 \%$ i $25 \%$ pacjentów. Przewidywany czas przeżycia u 55\% pacjentów wyniósł 5 lat. Mediana czasu do kolejnej linii terapii wyniosła 13 miesięcy.

$\mathrm{Na}$ podstawie powyższych danych obecnie zaleca się, aby u pacjentów $z$ grupy pośredniego ryzyka, o ile sytuacja kliniczna na to pozwala i nie ma możliwości zaproponowania chorym udziału $\mathrm{w}$ badaniach klinicznych, $\mathrm{w}$ pierwszej linii leczenia stosować schematy oparte na bortezomibie [11]. Jak dotąd $\mathrm{w}$ badaniach randomizowanych III fazy nie porównywano skuteczności klinicznej schematów BMDex i CyBorD w leczeniu pierwszej linii u pacjentów $z$ nowo rozpoznaną amyloidozą AL. Opierając się na danych retrospektywnych, schemat BMDex preferuje się u chorych $z$ dFLC przekraczającą $180 \mathrm{mg} / \mathrm{l}$, natomiast CyBorD u pacjentów $z$ zaawansowaną niewydolnością nerek lub obciążonych translokacją $\mathrm{t}(11 ; 14)$, a także $\mathrm{u}$ chorych $z$ potencjalnie odwracalnymi przeciwwskazaniami do auto-HSCT [7, 12]. U osób z zaawansowaną polineuropatią należy zrezygnować $z$ terapii opartej na bortezomibie; w tej grupie preferuje się schemat MDex [7, 11].

\section{Opis przypadku (3)}

Ze względu na obecność istotnej klinicznie polineuropatii czuciowej i autonomicznej odstąpiono od leczenia bortezomibem. Chorego zakwalifikowano do leczenia pierwszej linii w oparciu o schemat MDex. Leczenie prowadzono od stycznia do września 2016 roku; łącznie pacjent otrzymał 9 cykli leczenia. Osiągnął bardzo dobrą częściową odpowiedź hematologiczną i odpowiedź sercową, nie uzyskano natomiast odpowiedzi nerkowej.

Należy podkreślić, że decyzja o odstąpieniu od leczenia bortezomibem $\mathrm{u}$ chorego nie była podyktowana zajęciem mięśnia sercowego $\mathrm{w}$ przebiegu amyloidozy AL. Mimo sporadycznych opisów kardiotoksyczności bortezomibu rezygnacja ze stosowania tego leku u pacjentów $z$ amyloidozą AL serca w obawie przed zwiększonym ryzykiem powikłań kardiologicznych nie znajduje, jak dotąd, poparcia $\mathrm{w}$ danych klinicznych. Schematy oparte na bortezomibie $z$ powodzeniem stosuje się $\mathrm{u}$ chorych na amyloidozę serca. Zajęcie mięśnia sercowego stwierdzano u $73 \%$ pacjentów włączonych do badania, w którym oceniano skuteczność kliniczną schematu CyBorD w leczeniu pierwszej linii amyloidozy AL, przy czym odpowiednio 29\% i $20 \%$ stanowili pacjenci $\mathrm{z}$ amyloidozą AL w stopniu zaawansowania IIIa i IIIb według Mayo Clinic. Choć pacjenci z amyloidozą AL w stopniu zaawansowania IIIb charakteryzowali się gorszym rokowaniem, to uzyskanie odpowiedzi hematologicznej w czasie leczenia według schematu CyBorD (ORR 42\%) wiązało się poprawą przeżywalności również w tej grupie chorych [10].

Aktywność kliniczną schematu CyBorD oceniano również $\mathrm{w}$ grupie 60 pacjentów $\mathrm{z}$ zaawansowaną amyloidozą serca, a więc $\mathrm{w}$ stopniu III wedługg klasyfikacji Mayo Clinic 2004. Grupa ta jest obciążona szczególnie niekorzystnym rokowaniem, $z$ medianą OS wynoszącą 7 miesięcy i 12-miesięcznym przé̇yciem osiąganym tylko przez $46 \%$ chorych [13]. Leczenie według schematu CyBorD poprawiało rokowanie w tej grupie chorych. Odsetek obiektywnych odpowiedzi wyniósł $68 \%$, odpowiedź sercową uzyskano u $32 \%$ pacjentów, natomiast przewidywane przeżycie jednoroczne osiągnęło 57\% pacjentów [13]. Podobnie w przytoczonym wyżej badaniu III fazy zajęcie serca stwierdzano odpowiednio u $77 \%$ i $78 \%$ chorych na amyloidozę AL (włączano pacjentów $z$ amyloidozą $A L$ w stopniu zaawansowania IIIa wg klasyfikacji Mayo Clinic 2004 leczonych odpowiednio w grupach poddanych terapii MDex i BMDex. Nie wykazano istotnych różnic pod względem ciężkich działań niepożądanych w obu grupach [9].

Jakie dodatkowe leczenie należy rozważyć u chorego?

Zajęcie serca w przebiegu amyloidozy AL stanowi jeden $z$ głównych czynników prognostycznych, jak również znacząco determinuje postępowanie terapeutyczne. Znajduje to odzwierciedlenie $\mathrm{w}$ systemach oceny stopnia zaawansowania klinicznego amyloidozy AL, a także w kryteriach kwalifikacji do auto-HSCT $[1,11]$. Warto zaznaczyć, że w patogenezie postępującej niewydolności serca $\mathrm{w}$ amyloidozie serca bierze się pod uwagę nie tylko toksyczny wpływ depozytów amyloidowych, ale też (a nawet $\mathrm{w}$ większym stopniu) bezpośredni kardiotoksyczny wpływ nieprawidłowych FLC [1]. 
Chorzy z zajęciem serca w przebiegu amyloidozy AL wymagają czujnego nadzoru kardiologicznego. Co więcej, szczególnego znaczenia w odniesieniu do tej grupy pacjentów nabiera prowadzenie optymalnego leczenia wspomagającego, w tym również zastosowania doksycykliny — antybiotyku $z$ grupy tetracyklin, która wydaje się bezpośrednio wpływać na amyloidogenezę [15].

Zdolność doksycykliny, zarówno do interferencji w proces formowania się włókien amyloidowych [15], jak i znoszenia bezpośredniego działania toksycznego amyloidogennych łańcuchów lekkich na kardiomiocyty wykazano w badaniach podstawowych $[17,18]$. Pierwsze dane kliniczne sugerujące korzystny wpływ doksycykliny na wyniki leczenia chorych na amyloidozę AL przedstawili Kumar i wsp. [19]. Analizą objęto 455 pacjentów z amyloidozą AL poddanych auto-HSCT. Doksycyklinę stosowano w profilaktyce powikłań infekcyjnych po auto-HSCT u $23 \%$ pacjentów, pozostali chorzy natomiast otrzymywali pochodną penicyliny. Mediana OS w całej kohorcie wyniosła 161 miesięcy. Wśród chorych, którzy osiągnęli odpowiedź hematologiczną, leczenie doksycykliną wiązało się $z$ istotną poprawą OS (mediana OS $\mathrm{w}$ grupie chorych otrzymujących doksycyklinę i penicylinę, odpowiednio, nieosiagnięta i 161 miesięcy). Efektu tego nie obserwowano w grupie chorych, którzy nie uzyskali odpowiedzi hematologicznej.

Skuteczność kliniczną doksycykliny jako terapii wspomagającej $\mathrm{w}$ amyloidozie AL potwierdzono $\mathrm{w}$ wynikach analizy retrospektywnej przeprowadzonej przez Wechalekar i Whelan [20]. Objęto nią 30 pacjentów $z$ amyloidozą AL leczonych $w$ pierwszej linii według standardowego schematu chemioterapii (opartym na bortezomibie lub nie) w skojarzeniu $z$ doksycykliną, wyniki leczenia w grupie badanej porównywano $z$ wynikami dobranej grupy kontrolnej. Pacjenci leczeni doksycykliną znamiennie częściej osiągali odpowiedź hematologiczną (ORR $93 \%$ v. $59 \%)$ i odpowiedź sercową (60\% v. $18 \%)$. $\mathrm{Z}$ wyjątkiem chorych w stopniu zaawansowania IIIb według klasyfikacji Mayo Clinic, leczenie doksycykliną wiązało się $z$ istotną poprawą OS (mediana OS nieosiągnięta w grupie leczonych doksycykliną v. 13 miesięcy w grupie kontrolnej). Przeżycie 12i 24-miesięczne w grupie otrzymującej doksycyklinę osiągnęło, odpowiednio, $82 \%$ i $53 \%$ chorych $(v .82 \%$ i $40 \%$ w grupie kontrolnej). Korzyści z leczenia doksycykliną obserwowano w szczególności u chorych w stopniu zaawansowania IIIa, jak i z wysokim wyjściowym stężeniem troponiny T. Korzystny wpływ doksycykliny na wyniki leczenia stwierdzano również wśród chorych leczonych według schematów chemioterapii opartych na bortezomibie (mediana OS nieosiagnnięta $\mathrm{w}$ grupie leczonej doksycykliną v. 15 miesięcy w grupie kontrolnej) [20].

Ostatnio zainicjowano prospektywne badanie II fazy służące ocenie aktywności klinicznej doksycykliny podawanej doustnie w dawce 2 razy $100 \mathrm{mg} /$ dobę przez 12 miesięcy jako uzupełnienie standardowego leczenia wśród chorych na amyloidozę AL (badanie DUAL [Doxycycline to Upgrade Organ Response in Light Chain (AL) Amyloidosis]; NCT02207556) [21].

Dotychczas nie określono optymalnego czasu stosowania doksycykliny u chorych na amyloidozę AL, chociaż uważa się, że nie powinien on być krótszy niż 12 miesięcy. W przypadku utrzymującego się nieprawidłowego stosunku FLC i/lub wykrywalnego klonu nowotworowego oraz dobrej tolerancji doksycykliny racjonalna wydaje się również bezterminowa kontynuacja stosowania leku. Należy także podkreślić, że leczenie doksycykliną u chorego na amyloidozę AL odbywa się poza obowiązującymi obecnie wskazaniami rejestracyjnymi dla tego antybiotyku.

\section{Opis przypadku (4)}

U chorego zastosowano doksycyklinę podawaną doustnie w dawce 2 razy $100 \mathrm{mg} /$ dobę, począwszy od pierwszego cyklu chemioterapii MDex. Wobec dobrej tolerancji chory do dziś otrzymuje leczenie wspomagające doksycykliną (łącznie 30 miesięcy). Od grudnia 2016 roku utrzymuje się u niego odpowiedź hematologiczna; co więcej, obserwuje się stopniową redukcję stężenia NT-proBNP (ryc. 1, 2).

Chorzy $z$ amyloidozą serca narażeni są nie tylko na rozwój niewydolności serca $z$ zachowaną frakcją wyrzutową, ale także choroby wieńcowej, tachyarytmii nadkomorowych i komorowych oraz bradyarytmii [22]. Leczenie kardiologiczne stanowi wyzwanie $\mathrm{w}$ tej grupie chorych i powinno być prowadzone $\mathrm{w}$ ścisłym porozumieniu między hematologiem $\mathrm{i}$ kardiologiem. Należy podkreślić, że większość leków o uznanym działaniu w leczeniu niewydolności serca niezwiązanej $z$ amyloidozą $\mathrm{AL}$, takich jak inhibitory konwertazy angiotensyny II (ACE, angiotensin-converting enzyme) czy beta ${ }_{2}$-adrenolityki, może nie znajdować zastosowania u chorych na amyloidoze AL ze względu na złą tolerancję wynikającą głównie $z$ nasilenia objawów neuropatii wegetatywnej.

\section{Opis przypadku (5)}

W 2012 roku, a więc przed ustaleniem rozpoznania amyloidozy AL, u chorego rozpoznano 


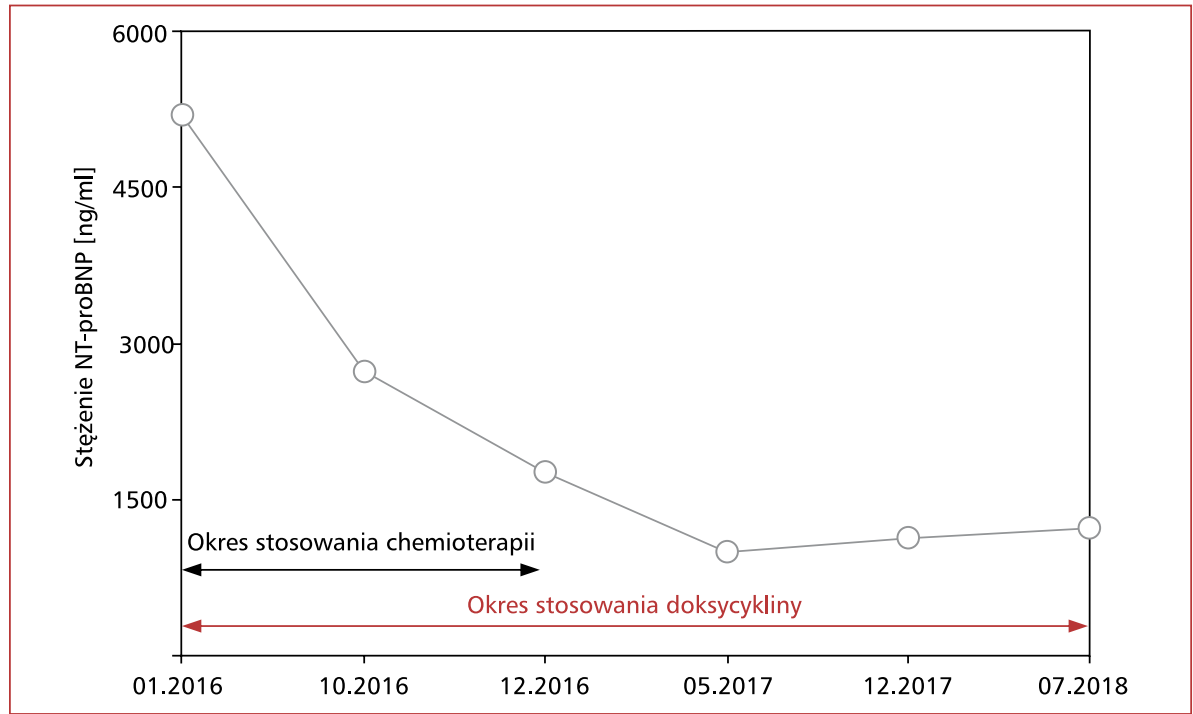

Rycina 1. Obserwowane u chorego obniżenie stężenia N-końcowego fragmentu propeptydu natriuretycznego typu B (NT-proBNP) w trakcie chemioterapii i leczenia doksycykliną

Figure 1. Reduction in patient's N-terminal pro-B-type natriuretic peptide (NT-proBNP) serum concentration observed during chemotherapy and doxycycline treatment

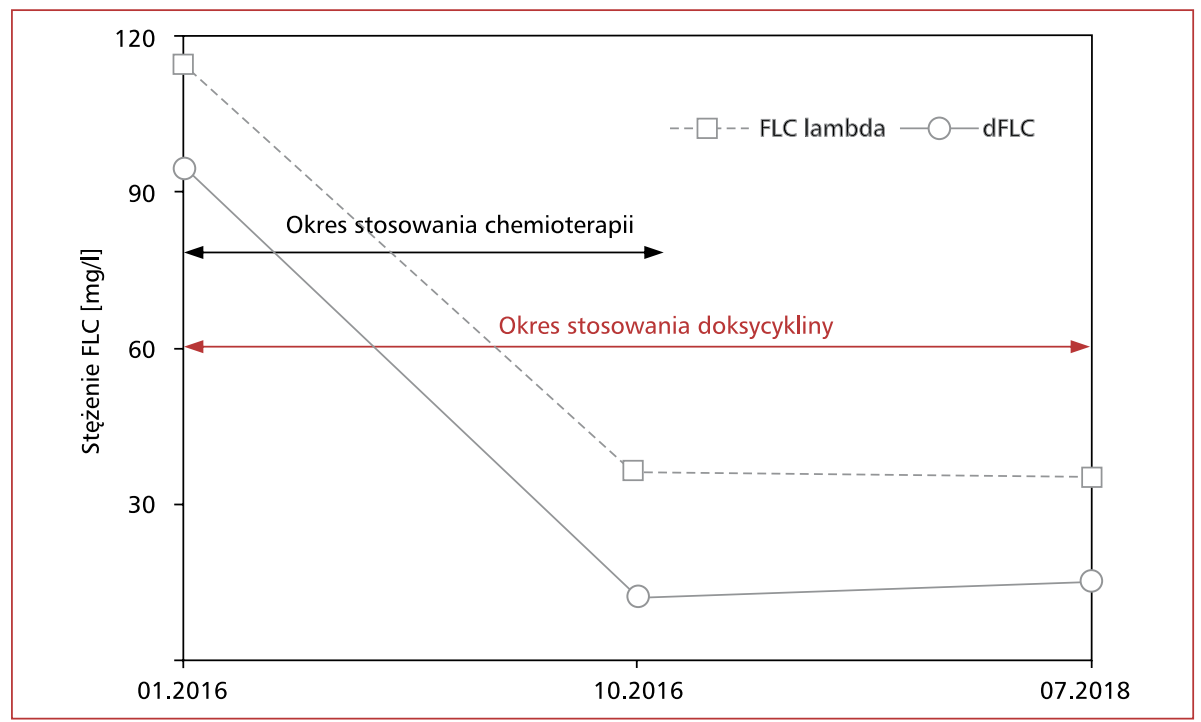

Rycina 2. Obserwowane u chorego obniżenie stężenia wolnych łańcuchów lekkich (FLC) lambda i różnicy stężeń między FLC klonalnym i nieklonalnym (dFLC) w trakcie chemioterapii i leczenia doksycykliną

Figure 2. Reduction in patient's lambda free light chains (FLC) serum concentration and difference between involved and uninvolved FLC (dFLC) observed during chemotherapy and doxycycline treatment

chorobę niedokrwienną serca pod postacią stabilnej dławicy piersiowej. Ze względu na stopień zaawansowania zmian miażdżycowych w tętnicach wieńcowych chorego zakwalifikowano do pomostowania aortalno-wieńcowego. W farmakoterapii stosowano beta-adrenolityki oraz inhibitory ACE.
Pacjenta poddano ponownej ocenie hematologicznej w lipcu 2018 roku. Potwierdzono utrzymywanie się hematologicznej VGPR i odpowiedzi sercowej, problemem pozostawały natomiast przetrwała hipotensja ortostatyczna, nawracające omdlenia, przetrwały białkomocz nerczycowy 
i stopniowo pogarszająca się funkcja nerek. W związ$\mathrm{ku} \mathrm{z}$ tym poszerzono diagnostykę omdleń, nie stwierdzając odchyleń w badaniu tomografii komputerowej głowy, w badaniu elektroencefalograficznym ani elektrokardiograficznym badaniu holterowskim. Choremu odstawiono beta-adrenolityk oraz inhibitor ACE, do leczenia włączono midodrynę - agonistę receptorów alfa ${ }_{1}$, który wykazuje aktywność w leczeniu hipotensji ortostatycznej [23].

Wobec niemożności wykluczenia komponenty neurologicznej, jako przyczyny obserwowanych omdleń, chorego skierowano na pogłębioną diagnostykę neurologiczną w ośrodku specjalistycznym. Podobnie, $w$ związku z podejrzeniem, że przyczyną pogorszenia parametrów wydolności nerek jest nefropatia niedokrwienna, chorego skierowano do ośrodka nefrologicznego $z$ doświadczeniem w leczeniu amyloidozy przebiegającej z zajęciem nerek.

Należy podkreślić, że w przypadku amyloidozy AL brak odpowiedzi narządowych nie powinien być automatycznym sygnałem do kontynuacji chemioterapii lub zmiany schematu leczenia, a głównymi kryteriami decydującymi o przebiegu terapii systemowej powinny być odpowiedź hematologiczna i tolerancja leczenia. Odpowiedzi narządowe występują tylko u części chorych i zwykle są opóźnione w stosunku do odpowiedzi hematologicznej. U niewielkiej części chorych nawet niewielkie stężenia krążących klonalnych FLC mogą prowadzić do progresji niewydolności narządowych, jednak u większości chorych osiągnięcie bardzo dobrej częściowej odpowiedzi hematologicznej zabezpiecza przed takim zjawiskiem. $Z$ drugiej strony agresywne zmiany chemioterapii wiążą się $z$ wysokim ryzykiem powikłań. $Z$ tych względów w przypadku stabilnej i głębokiej odpowiedzi hematologicznej należy zawsze wykluczyć inne przyczyny objawów narządowych i rozważyć korzyść i ryzyko z zastosowania chemioterapii.

\section{Podsumowanie}

Leczenie pacjenta $z$ amyloidozą AL stanowi wyzywanie w codziennej praktyce klinicznej. Choć uzyskanie głębokiej i długotrwałej odpowiedzi hematologicznej w głównej mierze decyduje o powodzeniu terapii, to $\mathrm{w}$ odniesieniu do tej grupy chorych szczególnego znaczenia nabiera odpowiednie prowadzenie leczenia wspomagającego. Chorzy na amyloidozę AL stanowią grupę wysokiego ryzyka ujawnienia się działań niepożądanych zarówno terapii ukierunkowanej na eradykację klonu plazmocytarnego, jak i leczenia schorzeń wspólistniejących.
Amyloidoza AL stanowi interdyscyplinarną jednostkę chorobową, należy więc położyć nacisk na to, aby przypadki amyloidozy AL leczono w ośrodkach specjalistycznych w ścisłej współpracy między hematologiem, kardiologiem, nefrologiem, gastroenterologiem, neurologiem i dietetykiem klinicznym.

\section{Konflikt interesów}

Autorzy deklarują brak konfliktu interesów.

\section{Piśmiennictwo}

1. Milani P, Merlini G, Palladini G. Light chain amyloidosis. Mediterr J Hematol Infect Dis. 2018; 10(1): e2018022, doi: 10.4084/ /MJHID.2018.022, indexed in Pubmed: 29531659.

2. Quock TP, Yan T, Chang E, et al. Epidemiology of AL amyloidosis: a real-world study using US claims data. Blood Adv. 2018; 2(10): 1046-1053, doi: 10.1182/bloodadvances.2018016402, indexed in Pubmed: 29748430.

3. Jamroziak K, Milani P, Puła B, et al. Diagnostyka i leczenie amyloidozy AL. Hematologia. 2018; 9(3): 181-195, doi: 10.5603/ /Hem.2018.0024.

4. Dispenzieri A, Gertz MA, Kyle RA, et al. Serum cardiac troponins and N-terminal pro-brain natriuretic peptide: a staging system for primary systemic amyloidosis. J Clin Oncol. 2004; 22: 3751-3757. J Clin Oncol. 2004; 22(18): 3751-3757, doi: 10.1200/ /JCO.2004.03.029.

5. Sidiqi MH, Aljama MA, Buadi FK, et al. Stem cell transplantation for light chain amyloidosis: decreased early mortality over time. J Clin Oncol. 2018; 36(13): 1323-1329, doi: 10.1200/ /JCO.2017.76.9554, indexed in Pubmed: 29558277.

6. Sanchorawala V, Sun F, Quillen K, et al. Long-term outcome of patients with AL amyloidosis treated with high-dose melphalan and stem cell transplantation: 20-year experience. Blood. 2015; 126(20): 2345-2347, doi: 10.1182/blood-2015-08-662726, indexed in Pubmed: 26443620.

7. Palladini G, Merlini G. What is new in diagnosis and management of light chain amyloidosis? Blood. 2016; 128(2): 159-168, doi: 10.1182/blood-2016-01-629790.

8. Dispenzieri A, Buadi F, Kumar SK, et al. Treatment of immunoglobulin light chain amyloidosis: Mayo stratification of myeloma and risk-adapted therapy (mSMART) Consensus Statement. Mayo Clin Proc. 2015; 90(8): 1054-1081, doi: 10.1016/j. mayocp.2015.06.009, indexed in Pubmed: 26250727.

9. Kastritis E, Leleu X, Arnulf B, et al. A Randomized phase III trial of melphalan and dexamethasone (MDex) versus bortezomib, melphalan and dexamethasone (BMDex) for untreated patients with AL amyloidosis. Blood. 2016; 128(22): e59-e60, doi: 10.1016/j.clml.2015.07.200.

10. Palladini G, Sachchithanantham S, Milani P, et al. A European collaborative study of cyclophosphamide, bortezomib, and dexamethasone in upfront treatment of systemic AL amyloidosis. Blood. 2015; 126(5): 612-615, doi: 10.1182/blood-2015-01-620302, indexed in Pubmed: 25987656.

11. Gavriatopoulou M, Musto P, Caers Jo, et al. European myeloma network recommendations on diagnosis and management of patients with rare plasma cell dyscrasias. Leukemia. 2018; 32(9): 1883-1898, doi: 10.1038/s41375-018-0209-7, indexed in Pubmed: 30038381. 
12. Merlini G, Wechalekar AD, Palladini G. Systemic light chain amyloidosis: an update for treating physicians. Blood. 2013; 121(26): 5124-5130, doi: 10.1182/blood-2013-01-453001, indexed in Pubmed: 23670179.

13. Wechalekar AD, Schonland SO, Kastritis E, et al. A European collaborative study of treatment outcomes in 346 patients with cardiac stage III AL amyloidosis. Blood. 2013; 121(17): 3420-3427, doi: 10.1182/blood-2012-12-473066, indexed in Pubmed: 23479568.

14. Jaccard A, Comenzo RL, Hari P, et al. Efficacy of bortezomib, cyclophosphamide and dexamethasone in treatment-naïve patients with high-risk cardiac $\mathrm{AL}$ amyloidosis (Mayo Clinic stage III). Haematologica. 2014; 99(9): 1479-1485, doi: 10.3324/haematol.2014.104109, indexed in Pubmed: 24859879.

15. Łyczkowska-Piotrowska J, Salomon-Perzyński A, Końska A, et al. Doksycyklina w terapii amyloidozy układowej z zajęciem serca. Hematologia. 2018; 9(3): 202-207, doi: 10.5603/Hem.2018.0027.

16. Ward JE, Ren R, Toraldo G, et al. Doxycycline reduces fibril formation in a transgenic mouse model of AL amyloidosis. Blood. 2011; 118(25): 6610-6617, doi: 10.1182/blood-2011-04-351643, indexed in Pubmed: 21998211.

17. Imperlini E, Gnecchi M, Rognoni P, et al. Proteotoxicity in cardiac amyloidosis: amyloidogenic light chains affect the levels of intracellular proteins in human heart cells. Sci Rep. 2017; 7(1): 15661, doi: 10.1038/s41598-017-15424-3, indexed in Pubmed: 29142197.

18. Diomede L, Rognoni P, Lavatelli F, et al. A caenorhabditis elegans-based assay recognizes immunoglobulin light chains causing heart amyloidosis. Blood. 2014; 123(23): 3543-3552, doi: 10.1182/ /blood-2013-10-525634, indexed in Pubmed: 24665135.

19. Kumar SK, Dispenzieri A, Lacy MQ, et al. Doxycycline used as post-transplant antibacterial prophylaxis improves survival in patients with light chain amyloidosis undergoing autologous stem cell transplantation. Blood. 2012; 120(21): 3138.

20. Wechalekar AD, Whelan C. Encouraging impact of doxycycline on early mortality in cardiac light chain (AL) amyloidosis. Blood Cancer J. 2017; 7(3): e546, doi: 10.1038/bcj.2017.26, indexed in Pubmed: 28338670.

21. D'Souza A, Flynn K, Chhabra S, et al. Rationale and design of DUAL study: doxycycline to upgrade response in light chain (AL) amyloidosis (DUAL): A phase 2 pilot study of a two-pronged approach of prolonged doxycycline with plasma cell-directed therapy in the treatment of AL amyloidosis. Contemp Clin Trials Commun. 2017; 8: 33-38, doi: 10.1016/j.conctc.2017.08.012, indexed in Pubmed: 29696194.

22. Dahm CN, Cornell RF, Lenihan DJ. Advances in Treatment of cardiac amyloid. Curr Treat Options Cardiovasc Med. 2018; 20(5): 37, doi: 10.1007/s11936-018-0631-1, indexed in Pubmed: 29627865.

23. Smith W, Wan H, Much D, et al. Clinical benefit of midodrine hydrochloride in symptomatic orthostatic hypotension: a phase 4 , double-blind, placebo-controlled, randomized, tilt-table study. Clin Auton Res. 2016; 26(4): 269-277, doi: 10.1007/s10286-016-0363-9, indexed in Pubmed: 27372462. 